\title{
A combined approach of remote sensing and airborne electromagnetics to determine the volume of polynya sea ice in the Laptev Sea
}

\author{
L. Rabenstein ${ }^{1}$, T. Krumpen ${ }^{2}$, S. Hendricks ${ }^{2}$, C. Koeberle ${ }^{2}$, C. Haas ${ }^{3}$, and J. A. Hoelemann ${ }^{2}$ \\ ${ }^{1}$ Institute of Geophysics, Swiss Federal Institute of Technology, Zurich, Switzerland \\ ${ }^{2}$ Alfred Wegener Institute for Polar and Marine Research, Bremerhaven, Germany \\ ${ }^{3}$ Department of Earth and Space Science and Engineering, York University, Toronto, Canada \\ Correspondence to: L. Rabenstein (rabenstein@aug.ig.erdw.ethz.ch) and T. Krumpen (thomas.krumpen@awi.de)
}

Received: 5 December 2012 - Published in The Cryosphere Discuss.: 1 February 2013

Revised: 30 April 2013 - Accepted: 20 May 2013 - Published: 19 June 2013

\begin{abstract}
A combined interpretation of synthetic aperture radar (SAR) satellite images and helicopter electromagnetic (HEM) sea-ice thickness data has provided an estimate of sea-ice volume formed in Laptev Sea polynyas during the winter of 2007/08. The evolution of the surveyed sea-ice areas, which were formed between late December 2007 and middle April 2008, was tracked using a series of SAR images with a sampling interval of 2-3 days. Approximately $160 \mathrm{~km}$ of HEM data recorded in April 2008 provided seaice thicknesses along profiles that transected sea ice varying in age from 1 to 116 days. For the volume estimates, thickness information along the HEM profiles was extrapolated to zones of the same age. The error of areal mean thickness information was estimated to be between $0.2 \mathrm{~m}$ for younger ice and up to $1.55 \mathrm{~m}$ for older ice, with the primary error source being the spatially limited HEM coverage. Our results have demonstrated that the modal thicknesses and mean thicknesses of level ice correlated with the sea-ice age, but that varying dynamic and thermodynamic sea-ice growth conditions resulted in a rather heterogeneous sea-ice thickness distribution on scales of tens of kilometers. Taking all uncertainties into account, total sea-ice area and volume produced within the entire surveyed area were $52650 \mathrm{~km}^{2}$ and $93.6 \pm 26.6 \mathrm{~km}^{3}$. The surveyed polynya contributed $2.0 \pm 0.5 \%$ of the sea-ice produced throughout the Arctic during the 2007/08 winter. The SAR-HEM volume estimate compares well with the $112 \mathrm{~km}^{3}$ ice production calculated with a high-resolution ocean sea-ice model. Measured modal and mean-level ice thicknesses correlate with calcu-
\end{abstract}

lated freezing-degree-day thicknesses with a factor of 0.87 0.89 , which was too low to justify the assumption of homogeneous thermodynamic growth conditions in the area, or indicates a strong dynamic thickening of level ice by rafting of even thicker ice.

\section{Introduction}

The coastal regions of the Arctic Ocean are characterized by transition zones between landfast and freely drifting sea ice during wintertime. The shoreward edges of these zones correlate in many cases with the $20 \mathrm{~m}$ isobath (Reimnitz et al., 1994). When local winds are directed away from the coast, open water, or so-called latent heat polynyas, is generated. The majority of Arctic polynyas reoccur along the coasts of Siberia, Alaska, and the western Canadian archipelago. The quasi-perennial polynyas of the Laptev Sea extend almost $2000 \mathrm{~km}$ along the coast and can be several hundred kilometers wide. Following Zakharov (1966), the prominent polynyas in the Laptev Sea are the AnabarLena (AL), eastern Severnaya Zemlya (ESZ), north-eastern Taymyr, New Siberian (NS), Taymyr (T), and western New Siberian (WNS) polynyas (Fig. 1). After initial freeze-up and before the onset of melting, the formation of sea-ice area in the Arctic Ocean is limited to polynyas and leads in the seaice cover. Their importance for the maintenance of the Arctic sea-ice volume and their impact on stratification in the Arctic Ocean is not completely understood. 


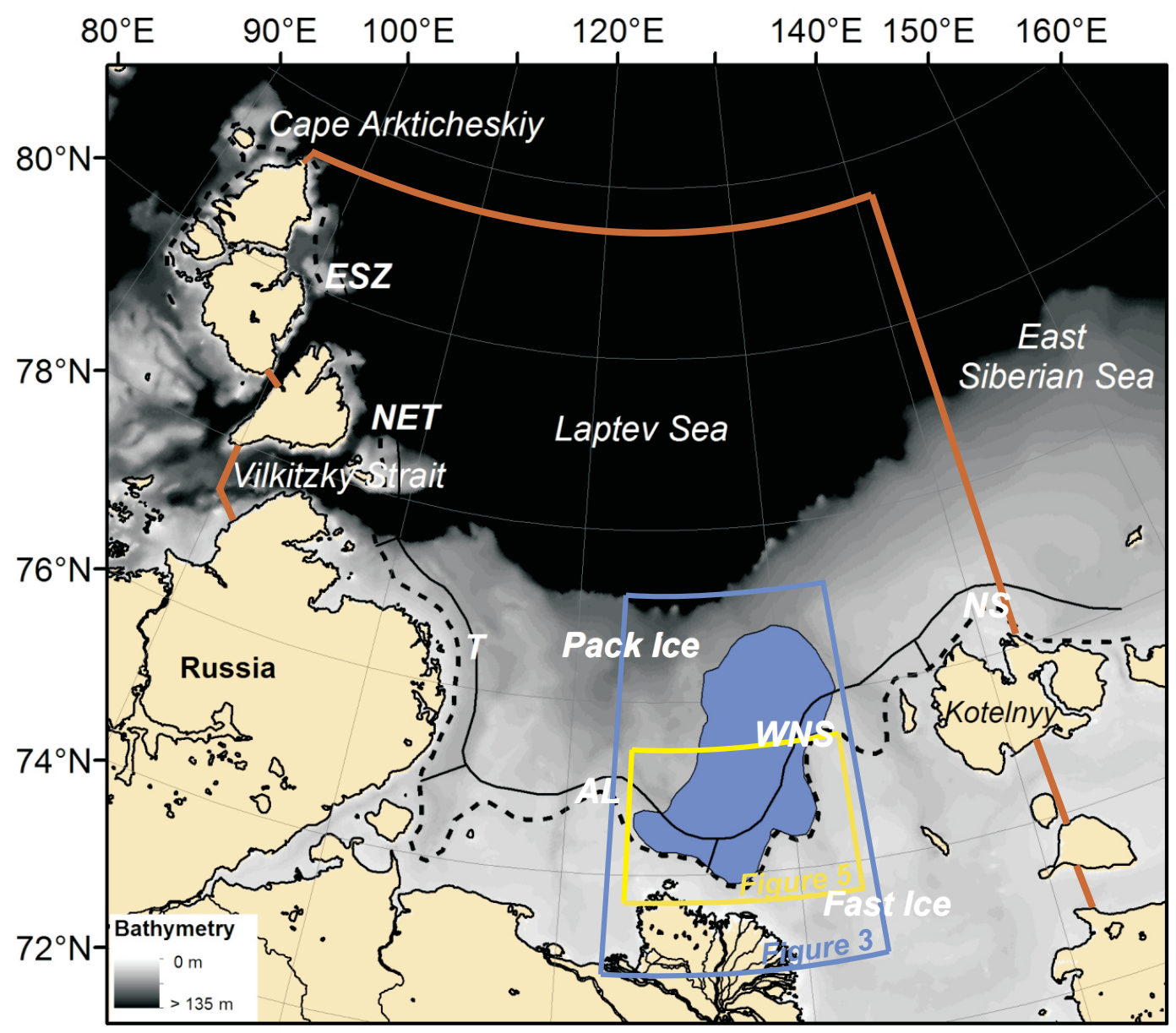

Fig. 1. Map of the Laptev Sea showing three distinct sea-ice components: fast ice, pack ice, and polynyas. Black solid and dashed lines delineate the mean lateral extent of fast ice and beginning of pack ice, respectively, at the end of winter. Polynyas that form between the two lines are the Anabar-Lena (AL), eastern Severnaya Zemlya (ESZ), north-eastern Taymyr (NET), New Siberian (NS), Taymyr (T), and western New Siberian (WNS) polynyas. Gray scale corresponds to the bathymetry (Smith and Sandwell, 1997). Blue area is the surveyed area comprising sea ice that formed during and after polynya openings between December 2007 and April 2008. Red line defines the outer skirt of the Laptev Sea. The blue and yellow frames indicate the outline of the areas shown in Figs. 3 and 5.

The Laptev Sea polynyas have been discussed in terms of ice production and the generation of higher saline water by several authors (Zakharov, 1966; Cavalieri and Martin, 1994; Dethleff et al., 1998; Dmitrenko et al., 2005, 2009; Willmes et al., 2010). Dmitrenko et al. (2009) have estimated the mean annual net sea-ice production in the entire Laptev Sea to be between $750 \mathrm{~km}^{3}$ and $1450 \mathrm{~km}^{3}$ on the basis of salinity observations within the upper $50 \mathrm{~m}$ of the water column. Annual sea-ice production rates for polynyas in the Laptev Sea have been estimated on the basis of net heat loss from ocean to atmosphere by Dethleff et al. $\left(1998,258 \mathrm{~km}^{3}\right.$ for the 1990/91 winter), Winsor and Bjork (2000, an average of $43 \mathrm{~km}^{3}$ for $\left.1958-1997\right)$ and Willmes et al. $\left(2011,55 \mathrm{~km}^{3}\right.$, average 1979-2008). These three studies differed in their definition of the polynya area: fixed in the study of Dethleff et al. (1998), varied according to atmospheric conditions in the study of Winsor and Bjork (2000), and determined on the basis of satellite-derived thin ice data in the study of Willmes et al. (2011). The sea-ice production definitions used in these investigations did not account for the evolution of sea-ice volume after the actual polynya events in the consolidating ice areas.

Here, we present an estimate of polynya sea-ice volume production in the Laptev Sea based on sea-ice area information derived from synthetic aperture radar (SAR) satellite images and helicopter electromagnetic (HEM) measurements of sea-ice thickness. In contrast to previous studies, we obtain sea-ice area and thickness directly with these methods. Since our volume estimates account for the evolution of seaice thickness after the formation of the polynyas, they cannot be directly compared with polynya production rates from previous studies. The HEM measurements were made during the Russian-German TRANSDRIFT XIII expedition to Tiksi (Krumpen et al., 2011). These data enable us to make a 


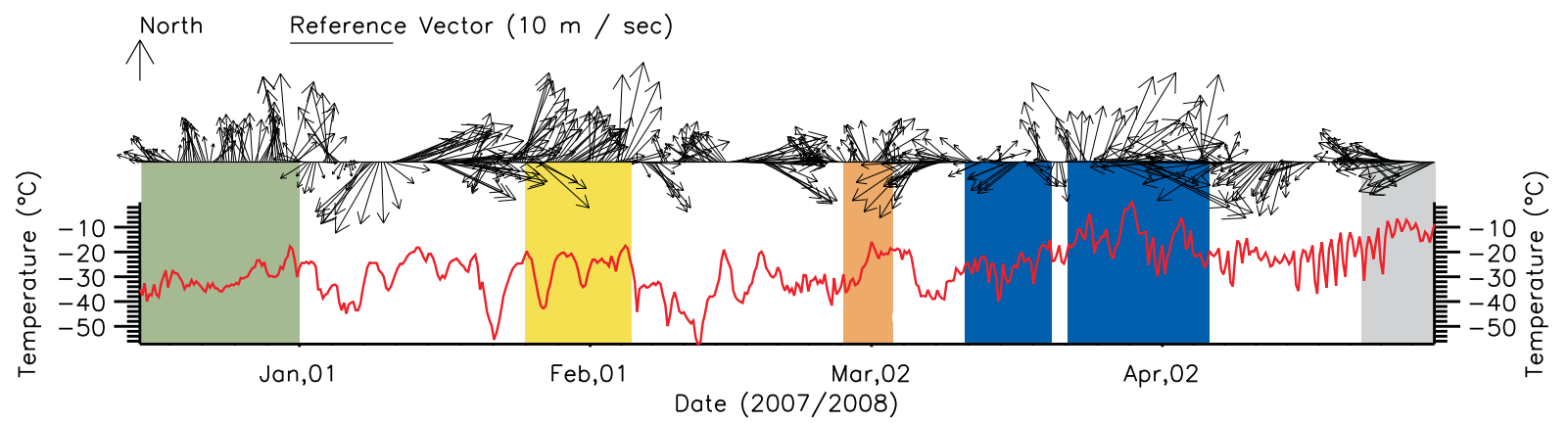

Fig. 2. Atmospheric data (NCEP/DOE, 6-hourly) for the 2007/2008 winter study period. Vectors along top of diagram show wind velocities (speeds and directions) of air flow (north-directed reference vector has $10 \mathrm{~ms}^{-1}$ speed), and main diagram depicts air temperatures $2 \mathrm{~m}$ above the ice surface. Each value represents a single point nominally in the center of the area of interest. Colored frames identify four polynya opening events. The fifth polynya event occurred after the HEM survey and is not considered in this study.

detailed analysis of thickness distributions for sea ice ranging in age from 1 to 116 days.

\section{Surveyed area, period and atmospheric conditions}

Our sea-ice area, thickness and volume estimates were made for a region covering the eastern part of the AL polynya and the southern part of the WNS polynya (Fig. 1). On average, these two polynyas are responsible for $57 \%$ of the entire polynya ice production in the Laptev Sea (Willmes et al., 2011). We have analyzed SAR satellite images for the time period 21 December 2007-16 April 2008. During this period, four major polynya opening events were generated by southerly or easterly winds (Fig. 2). Temperatures were mostly around $-30^{\circ} \mathrm{C}$ until the end of March when temperatures increased to about $-20^{\circ} \mathrm{C}$. According to Willmes et al. (2011), the 2007/2008 winter was characterized by slightly lower than average polynya activity in the Laptev Sea.

\section{Methods}

\subsection{SAR sea-ice tracking}

Several studies have shown that satellite SAR images are suitable for the manual tracking of such distinct ice features as perimeter shapes and ice ridges (Hall and Rothrock, 1981; Leberl et al., 1983; Curlander et al., 1985; Carsey and Holt, 1987). In the SAR images used in this study, newly formed sea ice was distinct, since it produced either a low backscatter image or, when frost flowers occurred, a very-high backscatter image (Nghiem et al., 1997), relative to the surrounding old ice. The known location of the fast ice edge and visible drift in two subsequent images was of additional help to identify new-ice areas.

The aim of our SAR sea-ice tracking was to delineate areas where new sea ice formed between sequential SAR scenes (every 2-3 days) and to follow the drift of these areas on all the subsequent scenes. We used SAR images generated by the wide-swath C-band antenna on ESA's Environmental Satellite (Envisat). The data were VV polarized and had a spatial resolution of $150 \times 150 \mathrm{~m}$. A subset of images covering a region of $600 \mathrm{~km}$ in a north-south direction and $300 \mathrm{~km}$ in an east-west direction was analyzed over a 116-day period. The output of our analysis were maps delineating different areas of sea ice, each having an approximately common formation time (Fig. 3). The shapes of newly formed ice change with progressing time and could be tracked for approximately 3 months before they became blurred, thus decreasing the accuracy of the area and age estimates. To compensate for the decreasing accuracy, we merged several older areas (see for example the green areas in Fig. 3f).

\subsection{HEM sea-ice thickness determination}

Electromagnetic induction methods have been used for seaice thickness determinations since the 1970s. They were first applied on the ice surface by Sinha (1976) and from a helicopter by Kovacs and Holladay (1990). Since then, a variety of sea-ice thickness studies have incorporated the results of airborne EM surveys (e.g., Multala et al., 1996; Prinsenberg et al., 2002; Rabenstein et al., 2010). For our study, the helicopter EM-Bird from the Alfred Wegener Institute (AWI) was employed (Haas et al., 2009) and the helicopter used was a Russian Mi-8. The EM signal was sampled 10 times per second, which for the average helicopter speed of $150 \mathrm{~km} \mathrm{~h}^{-1}$ provided a sample spacing of $4 \mathrm{~m}$. The AWI EMBird is especially designed for sea-ice thickness determination. Its $3.6 \mathrm{kHz}$ horizontal coplanar antenna loops are insensitive to the electrically resistive sea-ice layer but produced a good signal from the conductive ocean. As a consequence, the EM signal is inverse proportional to the height of the antenna above the ocean, such that the signal can be inverted for height, regardless of whether sea ice or air is between the antenna and ocean (Pfaffling et al., 2007); the ocean EM response for different flight heights can be calculated on the 
a.)

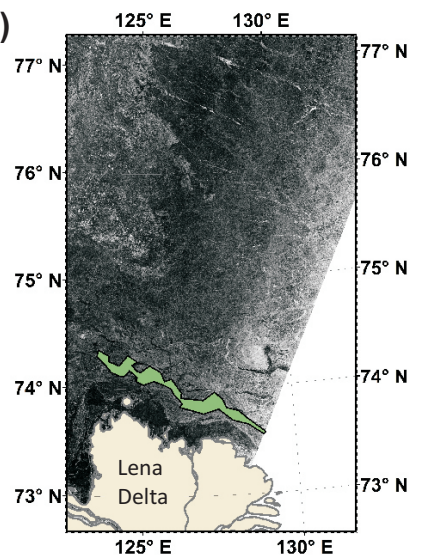

b.)

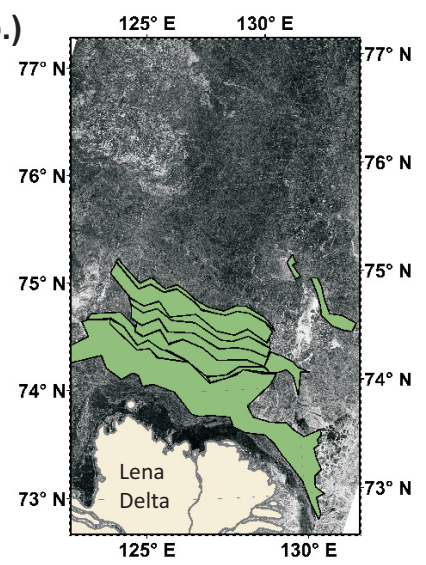

Opening Event 1
31.12 .2007

d.)

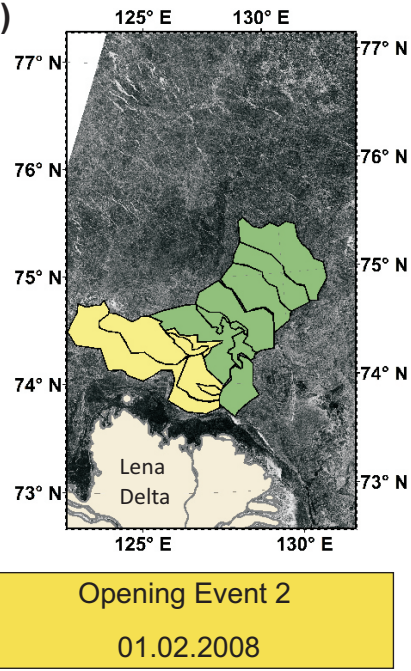

e.)

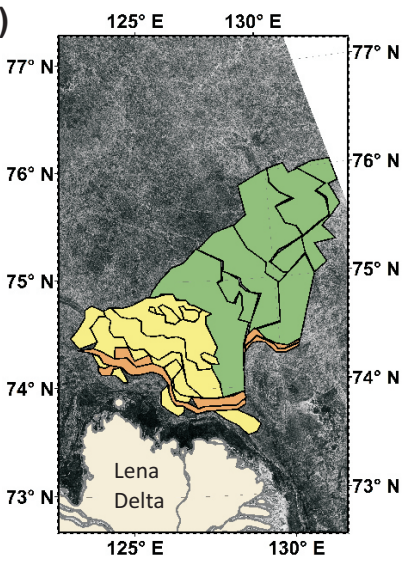

Opening Event 3

04.03.2008 c.)

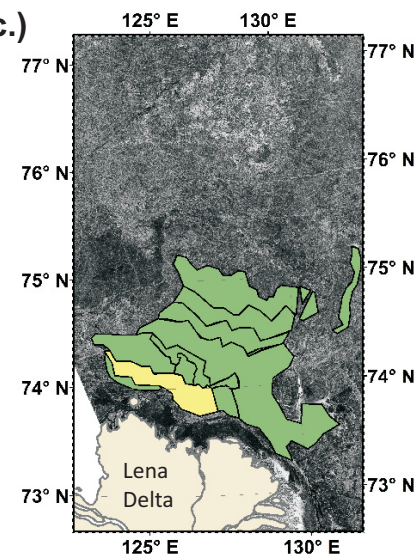

Opening Event 2

23.01.2008

f.)
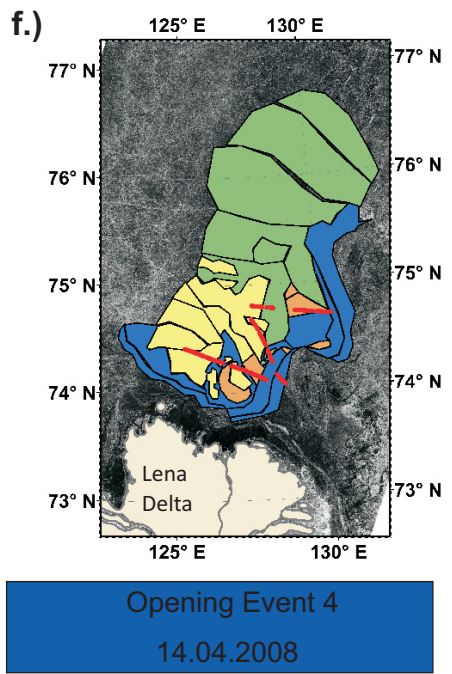

Fig. 3. Snapshots of sea-ice tracking on SAR satellite images. Areas contain sea ice formed after polynya opening events along the fast ice edge between 21 December 2007 and 14 April 2008: green - event 1 (December), yellow - event 2 (January), orange - event 3 (March), and blue - event 4 (April). Red lines in (f) are HEM sea-ice thickness profiles

basis of a 1-D model (Keller and Frischknecht, 1966). A laser altimeter is used to determine the vertical distance between the EM coils and the snow or ice surface, thus allowing the combined snow and sea-ice thicknesses to be estimated. For a typical flight height of 10-15 m, the accuracy of the combined snow and ice thicknesses was $0.1 \mathrm{~m}$ (Pfaffling and Reid, 2009). Since we are primarily interested in sea-ice thickness, we need to independently determine snow thickness. Fortunately, snow thickness in the survey region was on average smaller than $0.1 \mathrm{~m}$ based on several in situ spot measurements on the fast ice.

The HEM instrument averaged the ice thickness within its footprint, which was approximately $70 \mathrm{~m}$ for the inphase signal of the AWI EM-Bird towed at a height of $15 \mathrm{~m}$. Consequently, the instrument may have underestimated maximum thicknesses of ice ridges by up to $75 \%$ (Pfaffling and Reid,
2009). However, since the footprint effect acts like a smoothing average filter along the transect, the mean thickness for a sufficiently long transect is within the specified $0.1 \mathrm{~m}$ accuracy (Hendricks, 2009). To improve the accuracy of HEM ice thickness estimates, the EM-Bird was calibrated over open water. Unfortunately, strong variations of surface-water electrical conductivity in the region of interest hampered the open water calibrations. From in situ measurements, a surfacewater electrical conductivity range of $2.28 \mathrm{~S} \mathrm{~m}^{-1}$ close to the Lena River mouth to $2.5 \mathrm{~S} \mathrm{~m}^{-1} 140 \mathrm{~km}$ north of the river was observed (Krumpen et al., 2011). We took this range as the worst-case scenario for changes of sea-water electrical conductivity during one flight without recalibration, although we have no detailed information of the conductivity distribution between our in situ measurement spots. Assuming this worstcase variation, our thickness estimates may have an error of 


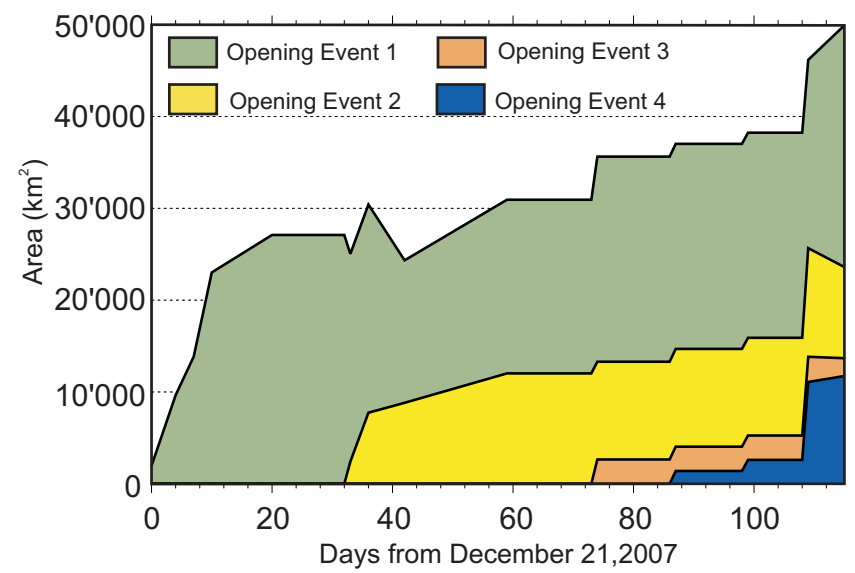

Fig. 4. Evolution of sea-ice area in $\mathrm{km}^{2}$ formed after polynya openings along the fast ice edge: green - event 1 (December), yellow - event 2 (January), orange - event 3 (March), and blue - event 4 (April).

as much as $0.2 \mathrm{~m}$ for a typical flight height of $15 \mathrm{~m}$. A more detailed description of sea-ice thickness determination using the airborne electromagnetic method is provided by Haas et al. (2009).

\section{Results and discussion}

There are four polynya opening events described below in terms of sea-ice production. A summary is provided in Table 1 .

\subsection{Sea-ice area production}

The spatial and temporal evolution of the tracked sea ice produced during the four polynya events is shown in Figs. 3 and 4. The first polynya event from the end of December (colored green in Figs. 2, 3 and 4) resulted in $\sim 27000 \mathrm{~km}^{2}$ of sea ice formed within 10 days. It was followed by the second event at the end of January when $\sim 12000 \mathrm{~km}^{2}$ of sea ice formed within 9 days (colored yellow). Approximately $2650 \mathrm{~km}^{2}$ of sea ice were generated during the third polynya event on 4 March (colored orange) and roughly $11000 \mathrm{~km}^{2}$ were produced in a 25-day period during the last series of opening events between March 13 and the beginning of April (colored blue). Area sizes changed after the initial polynya event due to convergent or divergent ice drift (Fig. 4). A clear decrease of about $5000 \mathrm{~km}^{2}$ was observed for areas of the first opening event 36-43 days after its origin (Fig. 4).

Establishing general error bounds for the sea-ice area estimates can be challenging, because the backscatter contrasts decrease as the new ice ages, making it difficult to map with confidence. Consequently, we can only state that the accuracy of picking is in the order of the pixel scale $(150 \mathrm{~m})$ for the early stages of ice production, progressively decreasing within 3 months to approximately $1000 \mathrm{~m}$. The total area of sea ice formed in the survey area during the study period was estimated to $\sim 52650 \mathrm{~km}^{2}$.

\subsection{Sea-ice thickness distribution}

Red lines in Fig. 3 identify the HEM sea-ice thickness profiles flown on 14 and 16 April. A relatively slow southwarddirected sea-ice drift of $1.6 \mathrm{~km}$ between these two days was taken into account in assigning the HEM thicknesses to the sea-ice areas of different age in Fig. 5. Profiles covering sections of different age are coded $14 \mathrm{a}-\mathrm{m}$ for the $13 \mathrm{sec}-$ tions recorded on 14 April and 16a-h for the 8 sections recorded on 16 April. Corresponding thickness transects and histograms are shown in Figs. 6 and 7. We applied the level ice filter of Rabenstein et al. (2010) to all thickness data in order to isolate sections of undeformed ice (i.e., sea ice formed from simple freezing processes). This filter identified $>100 \mathrm{~m}$ lengths of level ice over which the average thickness change per length was below $0.04 \mathrm{~m}$ per $4 \mathrm{~m}$, which was one sample interval. Sections of level ice are marked dark gray in the profiles of Fig. 6, and histograms of level ice are green in Fig. 7.

The youngest surveyed sea ice originated during event 4 . It was 7, 16, and 28 days old (blue sections in Figs. 5, 6 and 7). The 7-day-old ice was mostly level, had mean thicknesses of $0.2-0.7 \mathrm{~m}$ and became thicker with increasing offshore distance (e.g., section 14k in 6). This increase in thickness was due to the increasing age of the sea ice by one day or so with distance and the higher probability of rafting directed away from the fast ice edge (Krumpen et al., 2011). A somewhat surprising result was the thick 16-day-old ice in sections $16 \mathrm{c}$ and $16 \mathrm{f}$, with mean thicknesses of 1.9 and $2.4 \mathrm{~m}$. According to the SAR images, this 16-day-old ice began forming on March 28, and convergence with surrounding floes on March 30 caused a reduction of the freshly produced sea-ice area by $60 \%$. Consequently, sections $16 \mathrm{c}$ and $16 \mathrm{f}$ mostly comprise heavily deformed ice (e.g., piled rubble of thin ice blocks) and only small areas of level sea ice. However, such large mean thicknesses cannot be explained with the observed area reduction alone, and are therefore not representative. It is more likely that the thickness profile transected singular extreme features within this very irregularly shaped area (see Fig. 5).

Sea ice from event 3 (marked orange in Figs. 5, 6 and 7) differed in its degree of deformation. Sections $14 \mathrm{c}$ and $14 \mathrm{~d}$ (Fig. 6) are 47 days old. They have a much smaller percentage of level ice than the 49-day-old sea-ice in section 16b from the same event. Mean overall thicknesses of sea ice along all sections from event 3 are in the range of $1.1-1.5 \mathrm{~m}$ and level ice thicknesses from 0.6 to $0.8 \mathrm{~m}$. The thickest sea ice of event 3 is estimated to be $>5 \mathrm{~m}$. It occurs along section $16 \mathrm{~b}$, directly at the polynya edge adjacent to young, newly produced sea ice. Because of the $70 \mathrm{~m}$ footprint of the 


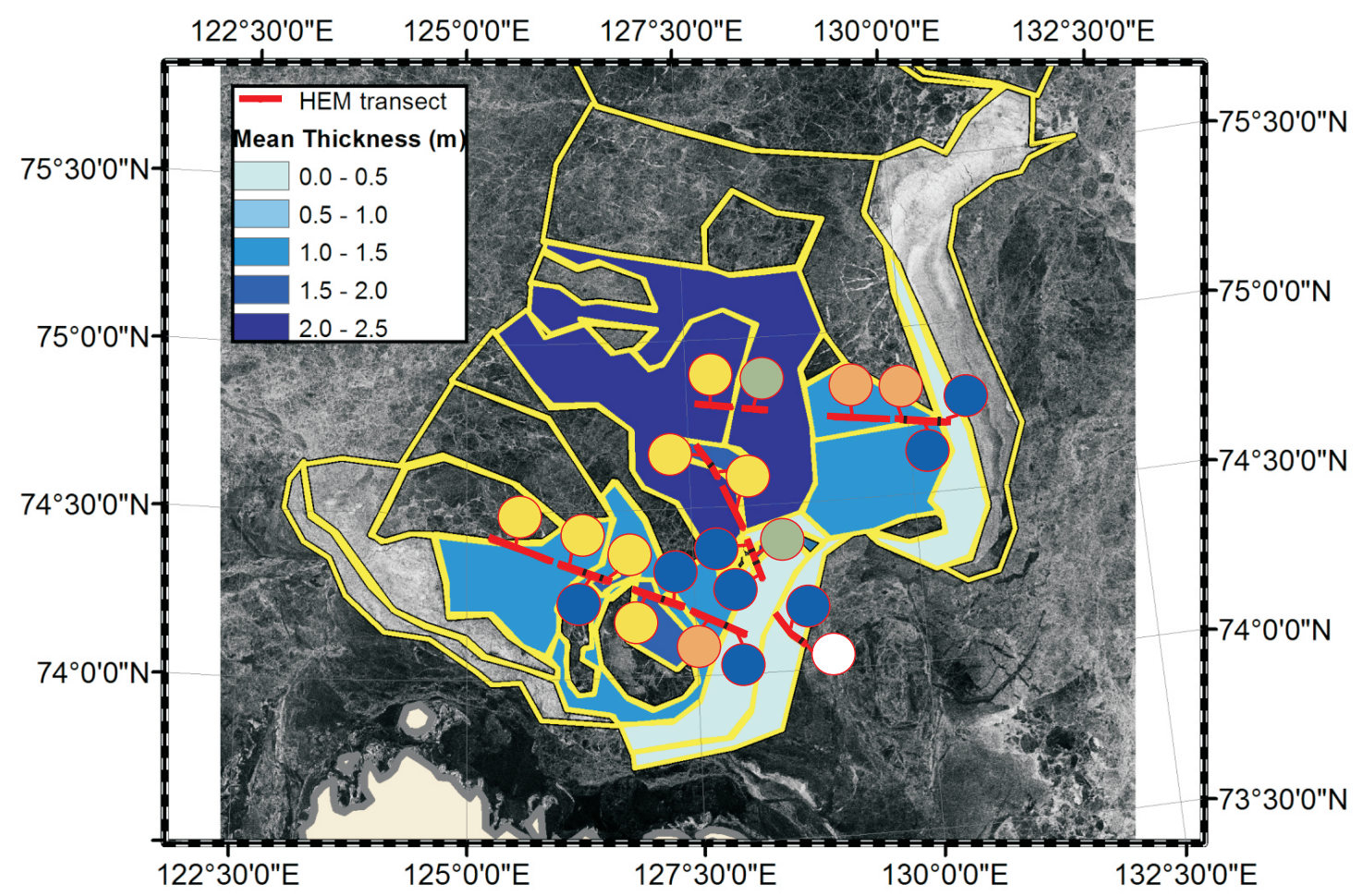

Fig. 5. Map with all HEM sea-ice thickness profiles. Northern and southern profiles flown on 14 and 16 April are coded $14 \mathrm{a}-\mathrm{m}$ and $16 \mathrm{a}-\mathrm{h}$, respectively. Circle colors refer to the polynya events in which the respective surveyed sea ice formed (for color code, see Table 1). The yellow lines on the SAR map show a classification of the survey area in zones of the same age. The blue colors refer to the mean thickness of the corresponding HEM cross profile.

Table 1. Parameters of sea ice originated during the four polynya events, estimated for the state on 14-16 April.

\begin{tabular}{lccccccccc}
\hline Event & Month & $\begin{array}{c}\text { Color } \\
\text { Code }\end{array}$ & $\begin{array}{c}\text { Age } \\
(\text { days })\end{array}$ & $\begin{array}{c}\text { Area } \\
\left(\mathrm{km}^{2}\right)\end{array}$ & $\begin{array}{c}\text { Mean } \\
\text { Thickness }(\mathrm{m})\end{array}$ & $\begin{array}{c}\text { Mean Thickness } \\
\text { Error }(\mathrm{m})\end{array}$ & $\begin{array}{c}\text { Volume } \\
\left(\mathrm{km}^{3}\right)\end{array}$ & $\begin{array}{c}\text { Volume } \\
\text { Error }\left(\mathrm{km}^{3}\right)\end{array}$ & $\begin{array}{c}\text { Level Ice } \\
\text { Thickness }(\mathrm{m})\end{array}$ \\
\hline 1 & Dec & green & $104-116$ & 27000 & $2.5-2.6$ & $1.6^{\mathrm{a}}$ & 64.8 & 20.3 & 1.9 \\
2 & Jan & yellow & $75-84$ & 12000 & $1.2-2.8$ & 1.6 & 19.8 & 4.3 & $1.0-1.8$ \\
3 & Mar & orange & 41 & 2650 & $1.1-1.4$ & 0.4 & 2.5 & 0.8 & $0.6-0.8$ \\
4 & Apr & blue & $7-28$ & 11000 & $0.2-2.4$ & $0.2^{\mathrm{b}}$ & 6.6 & 1.2 & $0.2-0.7$ \\
\hline Total & & & $7-116$ & 52650 & $0.2-2.8$ & $0.2-1.6$ & 93.6 & 27 & $0.2-1.9$ \\
\hline
\end{tabular}

${ }^{a}$ Due to lack of representative HEM thickness transects, set to the same value as the January event.

$\mathrm{b}$ Without the exceptional thick ice of section $16 \mathrm{c}$ and $16 \mathrm{f}$.

HEM instrument, the maximum thickness could be as much as $\sim 10 \mathrm{~m}$.

The second oldest ice is from event 2 (marked yellow in Figs. 5, 6 and 7). It shows a surprising variability for an age range of only 73-82 days. Mean ice thickness varies between 1.2 and $2.8 \mathrm{~m}$ and level ice thickness between 0.9 and $1.8 \mathrm{~m}$. After taking into account a very high HEM calibration error of $0.2 \mathrm{~m}$ and another $0.1 \mathrm{~m}$ of uncertainty due to snow cover (estimated from point measurements on the fast ice), our observations suggest that 82-day old level ice can be $0.7 \mathrm{~m}$ thicker than sea ice that is only 9 days younger. Even level ice thicknesses in areas of exactly the same age can vary by $\sim 0.2 \mathrm{~m}$ in our dataset. A possible mechanism causing such large thickness differences for equally old level ice is rafting, which has the potential to produce thicknesses between 2 and $6 \mathrm{~m}$ as was reported in several publications, which are summarized in Babko et al. (2002). However, when linking level ice thicknesses to thermodynamic growth (i.e., no rafting), reasons for such differences have to be caused by different heat flows from the ocean, a changing snowfall pattern and/or different air temperatures associated with open leads in the ice cover. 

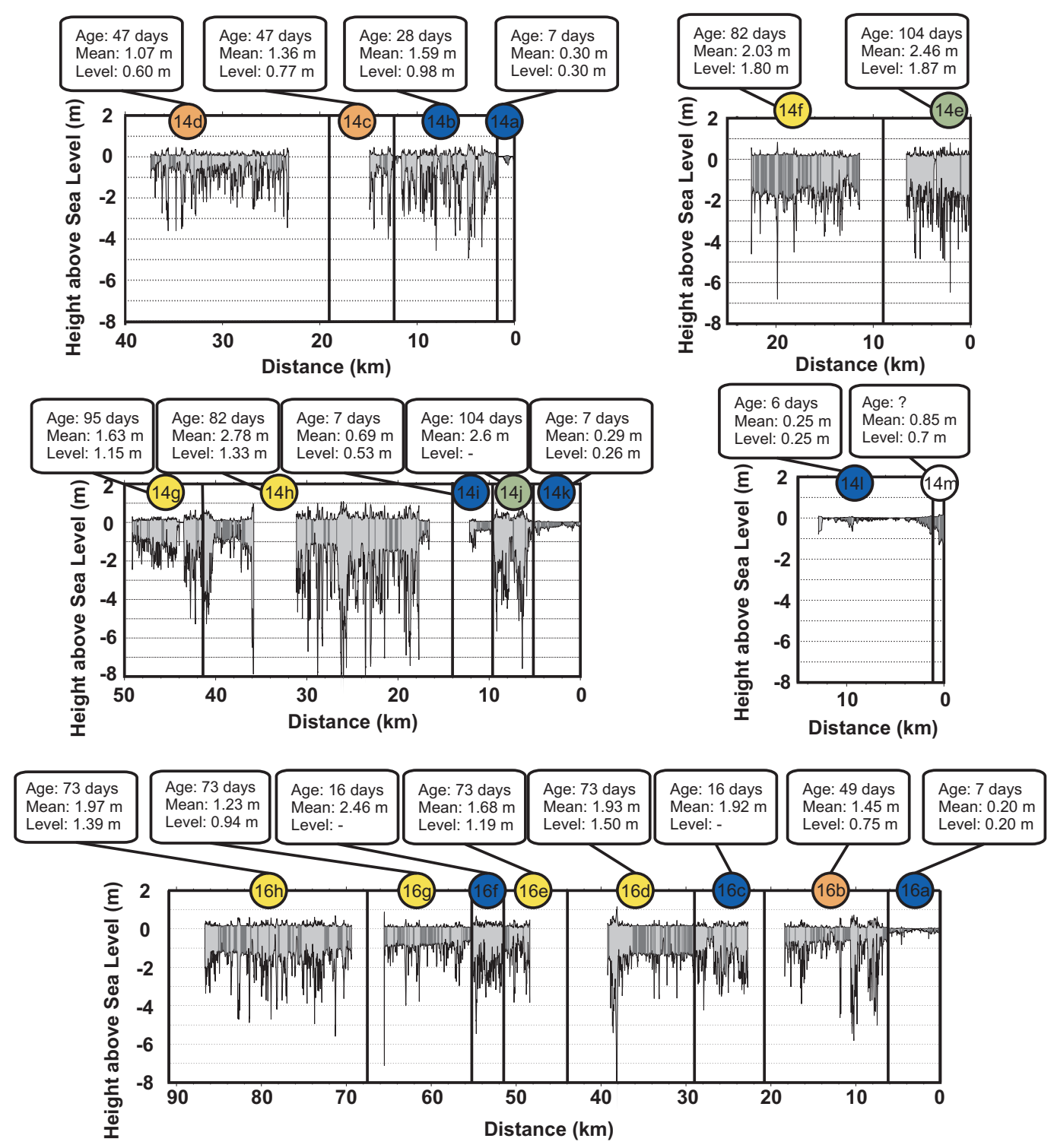

Fig. 6. Results of all HEM profiles shown in Fig. 5. For visualization, results are shown as draft-freeboard profiles, where a freeboard-draft ratio of 0.89 was assumed. Text boxes next to each draft-freeboard plot show age, mean thickness, and level ice thickness of the corresponding subsection. Zones of level ice in the profiles are highlighted dark. Circle colors refer to the polynya events in which the respective sea-ice profiles originated (for color code, see Table 1).

The oldest surveyed sections $14 \mathrm{e}$ and $14 \mathrm{j}$ (marked green in Figs. 5, 6 and 7) originated during event 1 and were approximately 104 days old. They had mean ice thicknesses of $2.5 \mathrm{~m}$ and $2.6 \mathrm{~m}$. Only section $14 \mathrm{e}$ contained a small and therefore unrepresentative amount of level ice with a mean thickness of $1.9 \mathrm{~m}$. Nevertheless, the histogram of section 14e (Fig. 7) shows a well-pronounced mode at $2.0 \mathrm{~m}$, which could be interpreted as thermally grown level ice (e.g., Haas, 2004).

\subsection{Sea-ice volume production}

We assume that a good approximation of new sea-ice volume in each region is the product of area with a representative mean thickness. We distinguish between two cases of mean thickness estimate. For the first case, the HEM profile crossed the area of interest, while the mean HEM thickness along the section was assumed to be representative of the entire area, and the thickness error was set to the HEM measurement error of $0.2 \mathrm{~m}$. For the second case, no HEM profile crossed the area of interest, while the thickness estimate was taken from areas of the same age that had been crossed by 

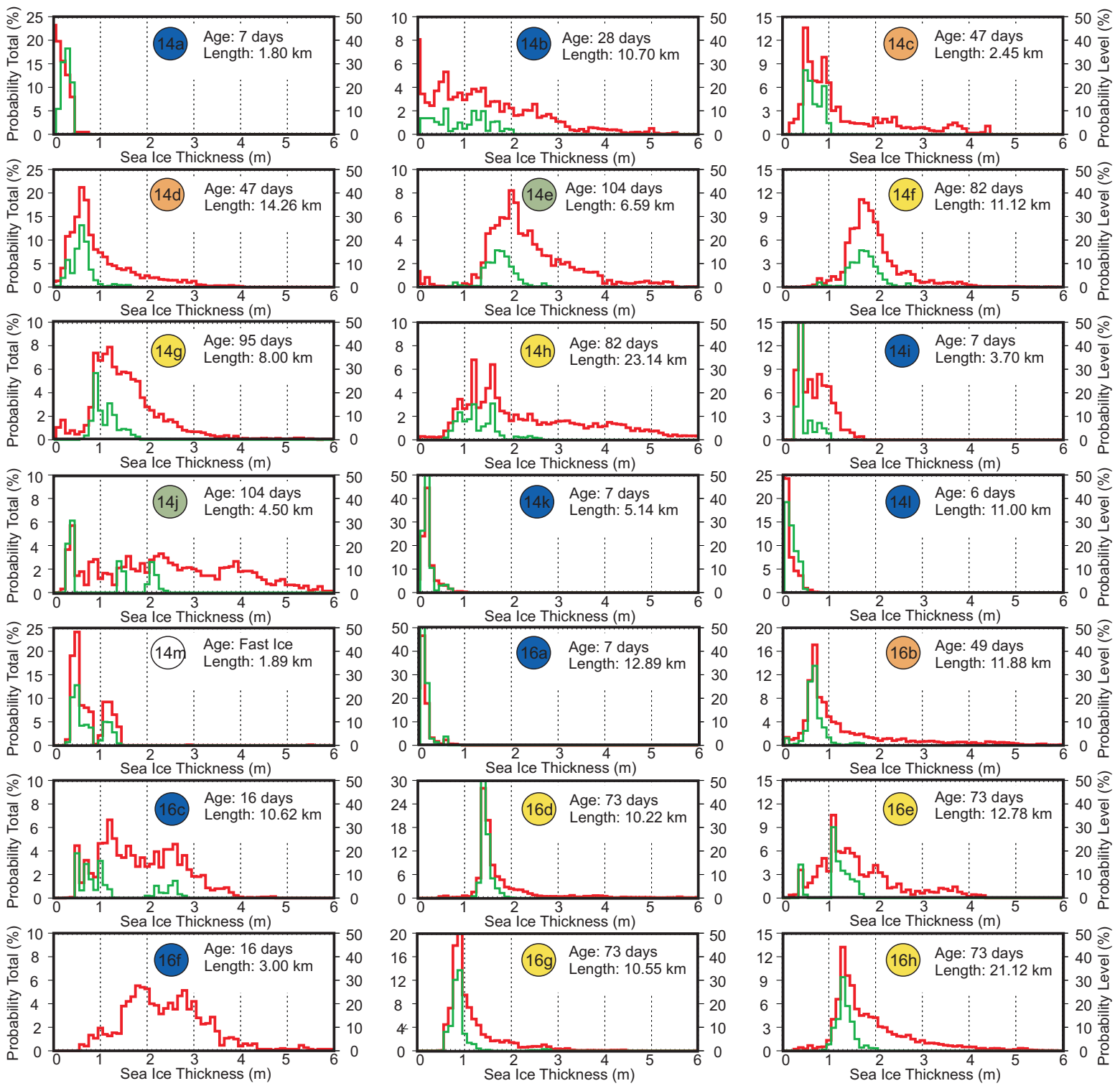

Fig. 7. Sea-ice thickness histograms of profiles shown in Figs. 5 and 6. Red histogram and axis on the left side of each diagram are for all ice thicknesses, whereas green histogram and axis on the right side of each diagram are for level ice only. No level ice was present in section $16 f$. Lengths of profiles and ages of the ice are shown in each diagram. Circle colors refer to the polynya events in which the respective sea-ice profiles originated (for color code, see Table 1).

an HEM profile, and the thickness error was presumed to be equal to the respective range of mean thicknesses. There are several exceptions to these two cases. Since areas of event 1 were not well sampled by HEM measurements (only sections $14 \mathrm{e}$ and $14 \mathrm{j}$ in Figs. 5, 6 and 7), we set their thickness error bounds to those of event 2. Mean thicknesses of the two exceptionally thick and deformed sections associated with event 4 (16c and 16f in Figs. 5, 6 and 7) are considered outliers, because no comparable area loss and related deformation were observed elsewhere in the study region. They were not taken into account for the second case error estimation.

Volume errors are highest for the areas of event 1, since most of them are not covered by HEM measurements, and smallest for event 4 , where only three areas were not sampled by HEM recordings (Table 1). Taking into account all errors and assumptions, the volumes of sea ice on 14-16 April that formed during events $1-4$ are $64.8 \pm 20.3,19.8 \pm 4.3,2.5 \pm$ 0.8 , and $6.6 \pm 1.2 \mathrm{~km}^{3}$, respectively (Table 1 ). In total, the sea-ice production amounted to $94 \pm 27 \mathrm{~km}^{3}$. 

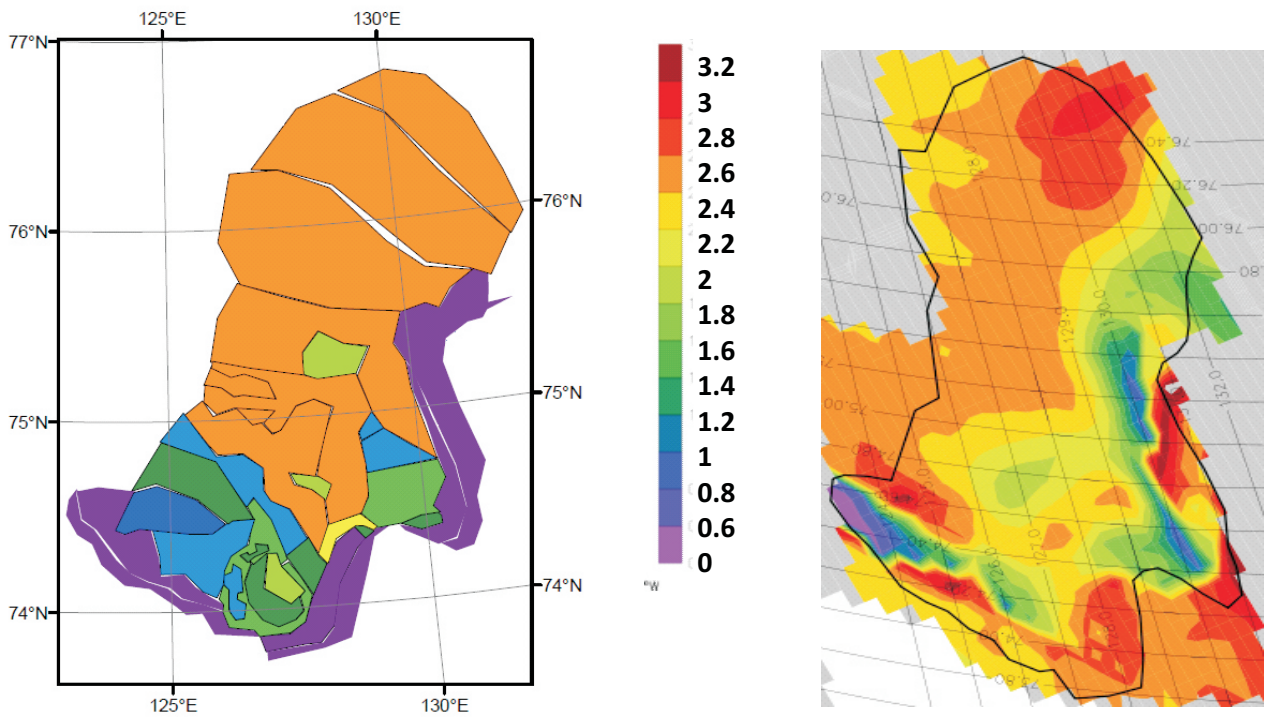

Fig. 8. Areas of sea ice that originated after polynya openings along the fast ice edge during the 116-day-long survey period. The color code refers to mean ice thickness. (a) Results from SAR tracking and HEM surveying. (b) Results from NAOSIM model.

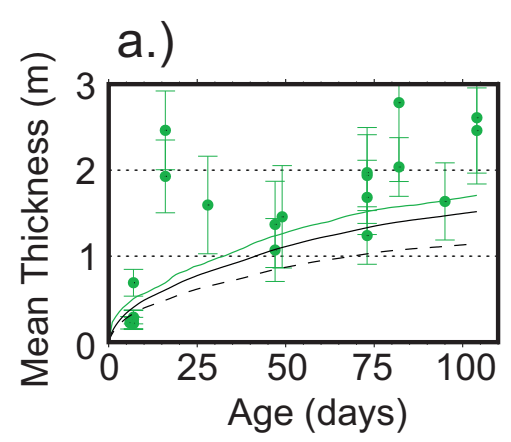

_ : based on NCEP data, no snow layer
_ : based on COSMO data, $10 \mathrm{~cm}$ snow layer

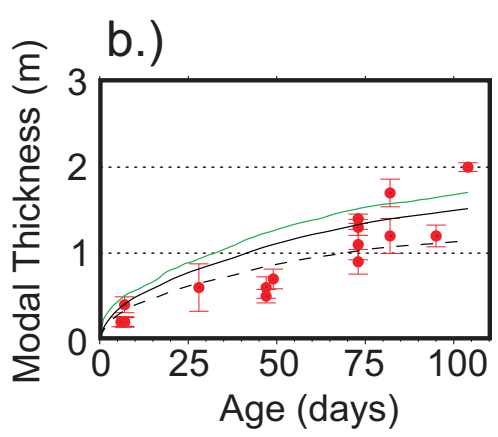

Age (days)

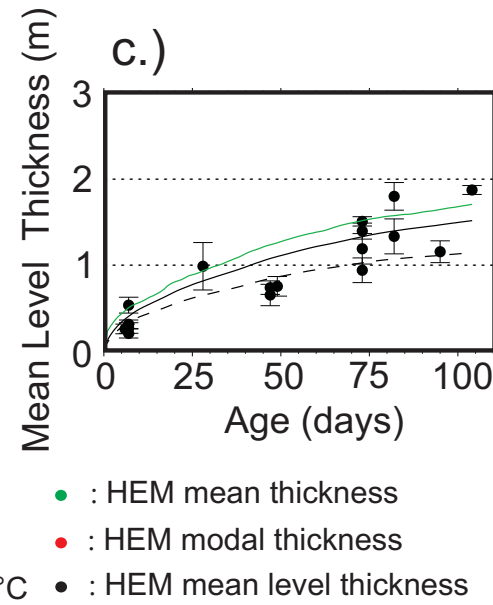

Fig. 9. Ice thickness versus age. Lines were calculated using a thermodynamic 1-D freezing-degree-day model based on Eq. (3) for one location in the survey area based on different air temperature data and snow thicknesses. (a) Comparison with mean-overall thicknesses (error bars show standard deviations within the corresponding HEM thickness profile). (b) Modal thicknesses (maxima of the histograms in Fig. 7). (c) Mean level ice thickness (similar to modal thicknesses in most cases). Error bars in (b) and (c) are standard deviations of level ice thickness within the corresponding HEM profile.

\subsubsection{Comparison of sea-ice volume to other studies}

It is not possible to quantitatively compare our total sea-ice volume estimate to the results of Dethleff et al. (1998), Winsor and Bjork (2000) and Willmes et al. (2011); we calculated a total sea-ice volume for a single two-day period (14-16 April) over a relatively large area, whereas the other studies integrated thin ice production rates over time within welldefined polynya areas. Our estimate includes the evolution of the polynya ice after it left a defined polynya area and is thus expected to be larger. We consider a comparison between our estimate and the output of a coupled ocean sea-ice model for the same region and period to be more meaningful.

We have conducted a model study simulating sea-ice production for the same region and time as our field investigation. The model was a high-resolution (1/12 degree horizontally) version of the NAOSIM coupled ocean sea-ice model (Fieg et al., 2010). The model consisted of a modified 
MOM2 ocean model coupled to dynamic-thermodynamic sea ice (Hibler, 1979). It included the Arctic Ocean, the Nordic seas, and the northern North Atlantic Ocean to $50^{\circ} \mathrm{N}$ on a rotated spherical grid. The boundaries were open. The atmospheric surface forcing was calculated from daily and 6-hourly (wind) NCEP data. The zones of immobile landfastened sea ice were determined by MODIS satellite observations (Adams et al., 2011; Rozman et al., 2011). We have analyzed mean model output from the end of December 2007 to the middle of April 2008.

Maps of mean sea-ice thickness based on our SAR-HEM investigation and the NAOSIM model output are compared in Fig. 8. The sea-ice area highlighted in Fig. $8 \mathrm{~b}$ is $49800 \mathrm{~km}^{2}$, assuming a complete sea-ice coverage for each grid cell. The ice volume within the polygon of Fig. $8 \mathrm{~b}$ is $112.2 \mathrm{~km}^{3}$ and lies within the range of our SAR-HEM estimate of $94 \pm 27 \mathrm{~km}^{3}$. In addition to the consistent total sea-ice volumes, the general distributions of ice thicknesses in Fig. 8a and $8 \mathrm{~b}$ are similar, with most of the thickest ice in the middle and northern regions and some of the thinnest ice near the southern and eastern margins of the maps. Despite this general agreement between both methods, in detail the thickness distributions differ owing to three facts: (1) the fast ice edge in the NAOSIM model is based on monthly means; (2) the model resolution is with $1 / 12$ degree $(9 \mathrm{~km}$ ) still coarse; and (3) the SAR-HEM approach has an averaging effect due to the limited coverage of the thickness measurements. Knowing that the total sea-ice volume of the NAOSIM model output is in good agreement with our SAR-HEM sea-ice volume estimations, we can quantify for the modeled Arctic Ocean that ice volume in the surveyed area was $6.2 \%$ of all the ice volume present in the Laptev Sea as defined in Fig. 1 $\left(1806 \mathrm{~km}^{3}\right)$ and $0.4 \%$ of all ice volume in the entire Arctic Ocean $\left(27740 \mathrm{~km}^{3}\right)$ on 16 April.

We can also assess the relevance of our total sea-ice volume estimate for the entire Laptev Sea by comparing it with the results of sea-ice volume calculations made by Dmitrenko et al. (2009). On the basis of surface-water salinity measurements, their average yearly sea-ice volume production within the entire Laptev Sea amounts to a number between $750 \mathrm{~km}^{3}$ and $1450 \mathrm{~km}^{3}$, which is roughly 8 to 15 times our estimated sea-ice volume. The contribution of all Laptev Sea polynyas to the value range of 750 to $1450 \mathrm{~km}^{3}$ can roughly be estimated on the basis of the following assumptions (Fig. 1):

1. Willmes et al. (2011) found that on average $57 \%$ of the polynya-related ice production takes place within the $\mathrm{AL}$ and WNS polynyas;

2. our survey covers ice that originated in polynyas along one-third of the fast ice edge of the AL and WNS polynyas;

3. the yearly polynya ice production is equally distributed along the fast ice edge of the AL and WNS polynyas.
Table 2. Parameters for the freezing-degree-day model: Eq. (1).

\begin{tabular}{cc}
\hline$k_{\mathrm{i}}$ & $2.03 \mathrm{~W} \mathrm{~m}^{-1} \mathrm{~K}^{-1}$ \\
$k_{\mathrm{S}}$ & $0.31 \mathrm{~W} \mathrm{~m}^{-1} \mathrm{~K}^{-1}$ \\
$C_{\mathrm{t}}$ & $0.24 \mathrm{~W} \mathrm{~m}^{-1} \mathrm{~K}^{-1}$ \\
$\rho_{\mathrm{i}}$ & $920 \mathrm{~kg} \mathrm{~m}^{-3}$ \\
$L$ & $295 \mathrm{~kJ} \mathrm{~kg}^{-1}$ \\
$T_{\mathrm{f}}$ & $-1.865^{\circ} \mathrm{C}$ \\
\hline
\end{tabular}

Table 3. Linear correlation coefficients between observed mean/modal/level thickness and modeled thermodynamic thickness.

\begin{tabular}{lccc}
\hline $\begin{array}{l}\text { Model } \\
\text { Database }\end{array}$ & $\begin{array}{c}\text { Total Mean } \\
\text { Thickness }\end{array}$ & $\begin{array}{c}\text { Modal } \\
\text { Thickness }\end{array}$ & $\begin{array}{c}\text { Level Mean } \\
\text { Thickness }\end{array}$ \\
\hline NCEP & 0.67 & 0.89 & 0.88 \\
COSMO 1 & 0.68 & 0.89 & 0.89 \\
COSMO 2 & 0.68 & 0.88 & 0.87 \\
\hline
\end{tabular}

As a direct consequence of assumptions 2 and 3, we multiply our $94 \pm 27 \mathrm{~km}^{3}$ sea-ice volume determination by three to estimate the entire production within the AL and WNS polynyas. Assumption 1 then allows us to estimate polynya sea-ice production for the entire Laptev Sea to be around $494 \pm 143 \mathrm{~km}^{3}$. This rough estimate suggests that around $34 \%$ to $65 \%$ of the Laptev Sea sea-ice volume is within ice areas that originated in polynyas. We stress that these arguments and estimates need to be viewed with caution, because we mix an annual average with measurements from one winter (2007/08), and Dmitrenko et al. (2009) themselves did not suggest any quantitative use of their estimate. For all comparisons, it is useful to know that the 2007/08 winter had below average polynya activity in the Laptev Sea (Willmes et al., 2011).

The relevance of our sea-ice volume estimate for the entire Arctic Ocean leads to somewhat different results as in the NAOSIM model, when we compare it to the calculations of Arctic-wide sea-ice volume based on satellite laser altimetry freeboard data (ICESat) published by Kwok et al. (2009). They calculated the total volume of sea ice in the Arctic Ocean averaged over a period of 35 days in February/March 2008 to be approximately $14000 \mathrm{~km}^{3}$ and the Arctic-wide ice production between October 2007 and March 2008 to be $4500 \mathrm{~km}^{3}$. Accordingly, our estimate of $94 \pm 27 \mathrm{~km}^{3}$ is $0.7 \pm 0.2 \%$ of the entire Arctic sea-ice volume and $2.0 \pm 0.5 \%$ of the Arctic-wide seasonal ice production in the 2007/08 winter. Moreover, our extrapolation of sea-ice production to all Laptev Sea polynyas $\left(494 \pm 143 \mathrm{~km}^{3}\right)$ is $3.5 \pm 1 \%$ of the entire Arctic sea-ice volume and $10 \pm 3 \%$ of the Arctic-wide sea-ice volume production in the $2007 / 08$ winter. 


\subsection{Age vs. thickness relations}

Our SAR-HEM data allow us to study the correlation between thickness and age of first year ice. We differentiate between three thickness statistics: the mean-overall, modal, and mean-level thicknesses. Theoretically, the thermodynamic growth of sea ice can be predicted as long as the heat budget of the ice surface is known. A straightforward way to calculate the thermodynamic growth of thin sea ice is the 1D freezing-degree-day model presented by Maykut (1986), which assumes that the temperature gradient within the ice is linear:

$H^{2}+\left[\frac{2 k_{\mathrm{i}}}{k_{\mathrm{s}}} h_{\mathrm{s}}+\frac{k_{\mathrm{i}}}{C_{\mathrm{t}}}\right] H=\frac{2 k_{\mathrm{i}}}{\rho_{\mathrm{i}} L} \theta$,

where $H$ is the ice thickness, $k_{\mathrm{i}}$ and $k_{\mathrm{S}}$ the thermal conductivities of ice and snow respectively, $h_{\mathrm{s}}$ the snow thickness, $C_{\mathrm{t}}$ a sensible and latent heat transfer coefficient, $\rho_{\mathrm{i}}$ the density of sea ice, $L$ the latent heat, and $\theta$ the freezing degree days described by the following integral:

$\theta \equiv \int_{t_{0}}^{t_{\mathrm{end}}}\left(T_{\mathrm{f}}-T_{\mathrm{a}}\right) \mathrm{d} t$

where $T_{\mathrm{f}}$ is the freezing temperature of sea water, $T_{\mathrm{a}}$ the air temperature, and $t_{0}$ corresponds to 21 December 2007 and $t_{\text {end }}$ to 16 April 2008. For $k_{\mathrm{i}}, k_{\mathrm{s}}, C_{\mathrm{t}}, L$ and $\rho_{\mathrm{i}}$, we used average values suggested by Maykut (1986) (Table 2) such that Eq. (1) becomes

$H^{2}+\left(13.1 h_{\mathrm{s}}+16.8\right) H=12.9 \theta$.

The validity of these parameters for the conditions in the Laptev Sea was shown by Krumpen et al. (2011). Thicknessversus-age plots are presented in Fig. 9. Standard deviations of the three thickness statistics (error bars in Fig. 9) describe the natural variability of ice thickness along the HEM profiles. This variability is largest for the mean-overall thickness, for which all ice classes are considered. The 1-D thermodynamic growth of sea ice was calculated for one position close to the polynya edge for three different atmospheric scenarios by solving Eq. (3) in the manner described by Krumpen et al. (2011). This growth is represented by the continuous lines in Fig. 9.

1. For the first set of calculations (green lines in Fig. 9), we used the air temperature data $2 \mathrm{~m}$ above ground taken from the $6 \mathrm{~h}$ NCEP/DOE reanalysis atmospheric forcing fields (Kanamitsu et al., 2002). These calculations do not account for snow coverage. NCEP data do not consider the open water area of polynyas, such that air temperatures are underestimated and sea-ice growth is overestimated. According to Ernsdorf et al. (2011), NCEP/DOE data overestimate temperatures by as much as $1.7 \mathrm{~K}$ close to the Laptev Sea polynyas.
2. For the second set of calculations (solid black lines in Fig. 9), we used 1-hourly data resulting from COSMO (Consortium for Small-Scale Modeling) simulations made for the Laptev Sea by Schroeder et al. (2011). In contrast to the NCEP/DOE reanalysis data, the COSMO dataset incorporates the impact of the polynyas on the atmospheric boundary layer. Snow cover was set to $0.1 \mathrm{~m}$ for this set of calculations. Estimated modal and mean-level ice thicknesses tend to be smaller than those determined from this second set of calculations (Fig. 9b, c).

3. The third set of calculations (dashed black lines in Fig. 9) was the same as the second set, except that snow cover was increased to $0.2 \mathrm{~m}$ and air temperature was increased by $2{ }^{\circ} \mathrm{C}$ relative to the COSMO data. The curve resulting from this third set of calculations matches some of the estimated modal and mean-level ice thicknesses better than that resulting from the second set of calculations. Points below a model curve imply thinner ice than physically possible for the given atmospheric parameters.

Linear correlation coefficients between modeled and estimated thicknesses for all three sets of calculations are listed in Table 3. Figure 9a and Table 3 demonstrate that meanoverall thickness is not strongly dependent on the age of sea ice that is at least $\sim 16$ days old. Differences in mean thickness of equally old ice can be as high as $1.55 \mathrm{~m}$, and the correlation coefficient between mean-overall thickness and age is only 0.68 . This low correlation is not surprising, because mean-overall thickness is strongly influenced by such dynamic growth processes as ridging and rafting (e.g., Thorndike et al., 1975; Parmerte and Coon, 1972; Babko et al., 2002), which are rather chaotic processes that are dependent on local wind conditions. This weak dependence is the reason for the comparatively large error bounds in our sea-ice volume estimates for areas not crossed by the HEM profiles. Relatively high correlations are observed between the modal and mean-level thicknesses and age (Fig. 9b, c and Table 3). Such high correlations are expected, since these two thickness statistics are assumed to reflect the thermodynamic growth of ice (e.g., Haas, 2004). Nevertheless, differences in modal and mean-level ice thicknesses for ice of the same age can be as large as $0.6 \mathrm{~m}$. From this observation, one could conclude that thermodynamic growth conditions can vary substantially within the surveyed region, such that a 1-D thermodynamic growth model for one position in the survey area cannot explain the variety of different level ice thicknesses within areas of the same sea-ice age. Alternatively, and as mentioned above, another reason for variable level ice thicknesses although atmospheric conditions are similar is rafting, which can also affect thicker sea ice (Babko et al., 2002). 


\section{Conclusion and outlook}

We have analyzed the production of sea ice that resulted from four polynya opening events in the Laptev Sea north of the Lena Delta. SAR satellite images were used to determine the area and age of the sea ice over the 116-day study period, and HEM data were used to determine sea-ice thickness along a number of profiles. These datasets provided new insights into the sea-ice thickness distribution of heterogeneous polynya sea ice. Our estimates of the area and the volume of ice formed in the surveyed polynyas were $52650 \mathrm{~km}^{2}$ and $94 \pm 27 \mathrm{~km}^{3}$. The large error in the volume estimate was largely based on the variability of mean thicknesses in sea-ice areas of the same age. A sea-ice volume estimate of $112.2 \mathrm{~km}^{3}$ derived from the NAOSIM ocean-seaice model agreed with the SAR-HEM-derived value within the error limits. A meaningful quantitative comparison of our results with those of other polynya sea-ice production studies in the Laptev Sea was not possible, because the definition of polynya ice differed in these studies. Based on the results of Kwok et al. (2009), we determined that sea-ice production associated with the four polynya events was $2 \pm 0.5 \%$ of the Arctic-wide sea-ice production during the 2007/08 winter.

We compared the age of sea-ice areas with their meanoverall, modal and mean-level thicknesses. There was only a weak correlation between age and mean-overall thickness for ice older than $\sim 16$ days. This weak correlation was the principal reason for the large error in our sea-ice volume estimate. Even modal or mean-level ice thicknesses did not correlate perfectly with the age of a surveyed ice area, although the correlation was higher than for the mean-overall thicknesses. The $0.87-0.89$ correlation coefficients between modeled 1-D freezing-degree-day thickness for atmospheric conditions at one location in the survey area and the modal and mean-level ice thicknesses were too low to justify the assumption of homogeneous thermodynamic growth conditions. Strong dynamic growth was indicated by 16-day-old sea ice that was completely deformed, with unexpectedly large thicknesses of 1.9 and $2.4 \mathrm{~m}$. We suspect that dynamic and thermodynamic growth conditions were laterally heterogeneous on a scale of tens of kilometers within the Laptev Sea.
Acknowledgements. Field work was completed during the TRANSDRIFT XIII expedition within the German-Russian cooperation System Laptev Sea funded by the Bundesministerium für Bildung und Forschung (BMBF) under grant 03G0639A. Logistics and instrumentation were supported by the Alfred Wegener Institute (AWI), Bremerhaven, Germany, and the Arctic and Antarctic Research Institute (AARI) in St Petersburg, Russia. We are also grateful to the members of the Lena Delta Reserve in Tiksi for help and logistics on site. Processing of the data and writing of the publication was completed at AWI Bremerhaven and at the Swiss Federal Institute of Technology (ETH) Zurich, Switzerland. Envisat SAR images were obtained through ESA AO-project AO500. We are indebted to the following persons: Torben Klagge from GEOMAR Kiel for technical field support; Heidemarie Kassens from GEOMAR, Ekaterina Taldenkova from Moscow State University; Viktor Visitov from AARI for administration, organization and negotiations in Tiksi; Sergey Kirillov, Andrey Novikhin and Michael Makhotin from AARI for help during the helicopter surveys; and Alan Green from ETH Zurich for a critical internal review of the paper. The COSMO dataset was kindly provided by the Environmental and Meteorology Department of the University Trier.

Edited by: D. Feltham

\section{References}

Adams, S., Willmes, S., Heinemann, G., Rozman, P., Timmermann, R., and Schroeder, D.: Evaluation of simulated seaice concentrations from sea-ice/ocean models using satellite data and polynya classification methods, Polar Res., 30, 7124, doi:10.3402/polar.v30i0.7124, 2011.

Babko, O., Rothrock, D., and Maykut, G.: Role of rafting in the mechanical redistribution of sea ice thickness, J. Geophys. Res., 107, 3113, doi:10.1029/1999JC000190, 2002.

Carsey, F. and Holt, B.: Beaufort-Chukchi ice margin data from Seasat - ice motion, J. Geophys. Res.-Oceans, 92, 7163-7172, doi:10.1029/JC092iC07p07163, 1987.

Cavalieri, D. and Martin, S.: The contribution of Alaskan, Siberian, and Canadian coastal polynyas to the cold halocline layer of the Arctic Ocean, J. Geophys. Res.-Oceans, 99, 18343-18362, 1994.

Curlander, J., Holt, B., and Hussey, K.: Determination of sea ice motion using digital SAR imagery, IEEE J. Ocean. Eng., 10, 358367, doi:10.1109/JOE.1985.1145134, 1985.

Dethleff, D., Loewe, P., and Kleine, E.: The Laptev Sea flaw lead - detailed investigation on ice formation and export during 1991/1992 winter season, Cold Reg. Sci. Technol., 27, 225-243, 1998.

Dmitrenko, I., Tyshko, K., Kirillov, S., Eicken, H., Holemann, J., and Kassens, H.: Impact of flaw polynyas on the hydrography of the Laptev Sea, Global Planet. Change, 48, 9-27, doi:10.1016/j.gloplacha.2004.12.016, 2005.

Dmitrenko, I. A., Kirillov, S. A., Tremblay, L. B., Bauch, D., and Willmes, S.: Sea-ice production over the Laptev Sea shelf inferred from historical summer-to-winter hydrographic observations of 1960s-1990s, Geophys. Res. Lett., 36, L13605, doi:10.1029/2009GL038775, 2009. 
Ernsdorf, T., Schroeder, D., Adams, S., Heinemann, G., Timmermann, R., and Danilov, S.: Impact of atmospheric forcing data on simulations of the Laptev Sea polynya dynamics using the sea-ice ocean model FESOM, J. Geophys. Res.-Oceans, 116, C12038, doi:10.1029/2010JC006725, 2011.

Fieg, K., Gerdes, R., Fahrbach, E., Beszczynska-Moeller, A., and Schauer, U.: Simulation of oceanic volume transports through Fram Strait 1995-2005, Ocean Dynam., 60, 491-502, doi:10.1007/s10236-010-0263-9, 2010.

Haas, C.: Late-summer sea ice thickness variability in the Arctic Transpolar Drift 1991-2001 derived from ground-based electromagnetic sounding, Geophys. Res. Lett., 31, L09402, doi:10.1029/2003GL019394, 2004.

Haas, C., Lobach, J., Hendricks, S., Rabenstein, L., and Pfaffling, A.: Helicopter-borne measurements of sea ice thickness, using a small and lightweight, digital EM system, J. Appl. Geophys., 67, 234-241, doi:10.1016/j.jappgeo.2008.05.005, 2009.

Hall, R. and Rothrock, D.: Sea ice displacement from Seasat synthetic aperture radar, J. Geophys. Res.-Oc. Atm., 86, 1078-1082, doi:10.1029/JC086iC11p11078, 1981.

Hendricks, S.: Validierung von altimetrischen Meereisdickenmessungen mit einem helikopterbasierten elektromagnetischen Induktionsverfahren, Ph. D. thesis, University Bremen, Bremen, Germany, 2009, (in German).

Hibler, W.: Dynamic thermodynamic sea ice model, J. Phys. Oceanogr., 9, 815-846, doi:10.1175/15200485(1979)009<0815:ADTSIM>2.0.CO;2, 1979.

Kanamitsu, M., Ebisuzaki, W., Woollen, J., Yang, S., Hnilo, J., Fiorino, M., and Potter, G.: NCEP-DOE AMIP-II reanalysis (R-2), Bull. Am. Meteorol. Soc., 83, 1631-1643, doi:10.1175/BAMS83-11-1631, 2002.

Keller, G. and Frischknecht, F.: Electrical Methods in Geophysical Prospecting, Oxford Pergamon Press, 1966.

Kovacs, A. and Holladay, J.: Sea-ice thickness measurement using a small airborne electromagnetic sounding system, Geophysics, 55, 1327-1337, 1990.

Krumpen, T., Hoelemann, J. A., Willmes, S., Maqueda, M. A. M., Busche, T., Dmitrenko, I. A., Gerdes, R., Haas, C., Heinemann, G., Hendricks, S., Kassens, H., Rabenstein, L., and Schroeder, D.: Sea ice production and water mass modification in the eastern Laptev Sea, J. Geophys. Res.-Oceans, 116, C05014, doi:10.1029/2010JC006545, 2011.

Kwok, R., Cunningham, G. F., Wensnahan, M., Rigor, I., Zwally, H. J., and Yi, D.: Thinning and volume loss of the Arctic Ocean sea ice cover: 2003-2008, J. Geophys. Res.-Oceans, 114, C07005, doi:10.1029/2009JC005312, 2009.

Leberl, F., Raggam, J., Elachi, C., and Campbell, W.: Sea ice motion measurements from Seasat SAR images, J. Geophys. Res.-Oc. Atm., 88, 1915-1928, doi:10.1029/JC088iC03p01915, 1983.

Maykut, G.: The surface heat and mass balance, 395-463, Martinus Nijhoff Publishers, Dordrecht (NATO ASI B146) Ed. N. Untersteiner, 1986.

Multala, J., Hautaniemi, H., Oksama, M., Lepparanta, M., Haapala, J., Herlevi, A., Riska, K., and Lensu, M.: An airborne electromagnetic system on a fixed wing aircraft for sea ice thickness mapping, Cold Reg. Sci. Technol., 24, 355-373, 1996.

Nghiem, S., Martin, S., Perovich, D., Kwok, R., Drucker, R., and Gow, A.: A laboratory study of the effect of frost flowers on $\mathrm{C}$ band radar backscatter from sea ice, J. Geophys. Res.-Oceans,
102, 3357-3370, doi:10.1029/96JC03208, 1997.

Parmerte, R. and Coon, M.: Model of pressure ridge formation in sea ice, J. Geophys. Res., 77, 6565-6575, doi:10.1029/JC077i033p06565, 1972.

Pfaffling, A. and Reid, J. E.: Sea ice as an evaluation target for HEM modelling and inversion, J. Appl. Geophys., 67, 242-249, doi:10.1016/j.jappgeo.2008.05.010, 2009.

Pfaffling, A., Haas, C., and Reid, J. E.: Direct helicopter EM - Seaice thickness inversion assessed with synthetic and field data, Geophysics, 72, 127-137, doi:10.1190/1.2732551, 2007.

Prinsenberg, S., Holladay, J., and Lee, J.: Measuring Ice Thickness with EISFlow, a fixed-mounted Helicopter Electromagneticlaser System, 12th International Offshore and Polar Engineering Conference, Conference Proceedings, 1, 737-740, 2002.

Rabenstein, L., Hendricks, S., Martin, T., Pfaffhuber, A., and Haas, C.: Thickness and surface-properties of different sea-ice regimes within the Arctic Trans Polar Drift: data from summers 2001, 2004 and 2007, J. Geophys. Res.-Oceans, 115, C12059, doi:10.1029/2009JC005846, 2010.

Reimnitz, E., Dethleff, D., and Nurnberg, D.: Contrasts in Arctic shelf sea-ice regimes and some implications - Beaufort Sea versus Laptev Sea, Mar. Geol., 119, 215-225, doi:10.1016/00253227(94)90182-1, 1994.

Rozman, P., Hoelemann, J. A., Krumpen, T., Gerdes, R., Koeberle, C., Lavergne, T., Adams, S., and Girard-Ardhuin, F.: Validating satellite derived and modelled sea-ice drift in the Laptev Sea with in situ measurements from the winter of 2007/08, Polar Res., 30, 7218, doi:10.3402/polar.v30i0.7218, 2011.

Schroeder, D., Heinemann, G., and Willmes, S.: The impact of a thermodynamic sea-ice module in the COSMO numerical weather prediction model on simulations for the Laptev Sea, Siberian Arctic, Polar Res., 30, 6334, doi:10.3402/polar.v30i0.6334, 2011.

Sinha, A.: A field study for sea-ice thickness determination by electromagnetic means, Geol. Surv. Can. Paper, 76, 225-228, 1976.

Smith, W. and Sandwell, D.: Global sea floor topography from satellite altimetry and ship depth soundings, Science, 277, 19561962, doi:10.1126/science.277.5334.1956, 1997.

Thorndike, A., Rothrock, D., Maykut, G., and Colony, R.: Thickness distribution of sea ice, J. Geophys. Res.-Oc. Atm., 80, 45014513, 1975.

Willmes, S., Krumpen, T., Adams, S., Rabenstein, L., Haas, C., Hoelemann, J., Hendricks, S., and Heinemann, G.: Crossvalidation of polynya monitoring methods from multisensor satellite and airborne data: a case study for the Laptev Sea, Can. J. Remote Sens., 36, 196-210, 2010.

Willmes, S., Adams, S., Schroeder, D., and Heinemann, G.: Spatiotemporal variability of polynya dynamics and ice production in the Laptev Sea between the winters of 1979/80 and 2007/08, Polar Res., 30, 5971, doi:10.3402/polar.v30i0.5971, 2011.

Winsor, P. and Bjork, G.: Polynya activity in the Arctic Ocean from 1958 to 1997, J. Geophys. Res.-Oceans, 105, 8789-8803, 2000.

Zakharov, V.: Role of flaw leads off edge of fast ice in hydrological and ice regime of Laptev Sea, Oceanology-USSR, 6, 815-821, 1966. 